\title{
Correction to: Advances in the utilisation of castor (Ricinus communis Linneo) seed meal as protein supplement in poultry diets
}

\author{
Siaka Seriba Diarra $\cdot$ Alireza Seidavi $\mathbb{C}$
}

Published online: 19 February 2019

(C) Springer Nature B.V. 2019

Correction to: Agroforest Syst

https://doi.org/10.1007/s10457-018-0317-4

Unfortunately, in the original publication of the article the article type was inadvertently published as
"Original Paper". The corrected article type should read as "Review Paper".

Publisher's Note Springer Nature remains neutral with regard to jurisdictional claims in published maps and institutional affiliations.

The original article can be found online at https:// doi.org/10.1007/s10457-018-0317-4.

\section{S. S. Diarra}

School of Agriculture and Food Technology, The University of the South Pacific, Alafua Campus, Apia, Samoa
A. Seidavi $(\bowtie)$ Department of Animal Science, Rasht Branch, Islamic Azad University, Rasht, Iran
e-mail: alirezaseidavi@iaurasht.ac.ir 